\title{
Fighting with films
}

\section{Diego Mollá Furió* y Josep Gavaldà Roca}

\author{
Universidad de Valencia, España
}

Recibido: 17 de noviembre 2016; aceptado: 28 de febrero 2017

\section{Resumen}

El artículo analiza el discurso cinematográfico norteamericano, informativo y de ficción, del periodo de la Primera Guerra Mundial. Inscribe el trabajo de "the division of films" en el marco de la compleja campaña de comunicación institucional desplegada por el gobierno de W. Wilson tras la declaración de guerra, analizando las estrategias "publicitarias" y "de propaganda" del Committee on Public Information, creado ad hoc para la campaña bélica. Se estudia, por una parte, el aparato de distribución de los relatos cinematográficos documentales y de ficción tanto en el mercado norteamericano como en el mercado internacional, las medidas administrativas y los organismos implicados, especialmente en la distribución internacional. Por otra, se estudia el modelo de producción tanto en lo relativo a los contratos firmados con las principales productoras norteamericanas como en lo relativo a la organización de la que se dotó el Committee on Public Information para realizar sus propias producciones y participar en proyectos de coproducción con las empresas cinematográficas. Se prestará especial atención a la "teoría" desarrollada por el Committee on Public Information, en lo relativo a la escritura del guión y en lo relativo a la puesta en escena de los films, sobre todo en el caso de los relatos documentales, para los que se habilitó un modelo, basado en su hibridación con los relatos de ficción, que perseguía estimular la demanda de un cine "educativo", de "propaganda”, frente al que los exhibidores mostraron en un principio no pocas resistencias. El estudio prestará especial atención a la categorización de que es objeto la representación icónica, en términos generales, y, en particular, la valoración que se hace del papel que puede desempeñar el silent cinema en el desarrollo de las estragegias comunicativas del Committe on Public Information. A pesar de la prevención con que el Comité utiliza la categoría de "propaganda", como lo atestigua su propia denominación, a la representación icónica se le reconocerá el "máximo valor propagandístico", concediéndole lugar de privilegio, en especial, en la campaña internacional llamada a difundir por todo el planeta "the gospel of americanism”.

Palabras Clave: Comunicación política | Propaganda | Publicidad | Discurso Cinematográfico | Análisis del discurso.

Fighting with films

\begin{abstract}
The article analyzes film discourse, both informative and fiction, in the United States during the First World War. The article places "the division of films" in the framework of the complex campaign of institutional communication started by W. Wilson's government after the war declaration by analyzing "publicity" and "propaganda" strategies deployed by the Committee on Public Information, which was created ad hoc for the military campaign. On the one hand, the paper explores the film stories, both documentary and fiction, distribution apparatus in both the United States and the international markets, the administration policies and the involved agencies, especially in the international distribution. On the other hand, it examines the model of production concerning the contracts signing with film companies and the organization adopted by the Committee on Public Information to create its own productions and participate in joint projects with film companies. The paper places emphasis on the "theory" developed by the Committee on Public Information about script-writing and film staging, particulary on the case of documentary stories, which were based in a model, hybridized with fiction stories, in order to stimulate demand for "educational", "propaganda" film-making, to which the exhibitors initially showed signs of resistence. The paper also highlights, in overall terms, how iconical representation was categorized and, in particular, the assessment on the role silent cinema can play in the Committee's development of communicative strategies. In spite of the Comittee's avoidance of the "propaganda" category, as its own name shows, iconical representation was given "highest propaganda value" and was granted a place of privilege, particularly, in the international campaign's call to spread "the gospel of americanism" around the globe.
\end{abstract}

Keywords: Political Communication | Propaganda | Publicity/Advertising | Film Discourse | Discourse Analysis

\section{"Fighting with films"}

George Creel publicó, el año 1920, How We Advertised America, ${ }^{1}$ historia oficial de un organismo de "propaganda”, el Committee on Public Information, y manual de comunicación de guerra pionero. Se trata de un discurso enunciado en primera persona del plural, de acuerdo con las reglas de la épica patriótica. Quien había tenido el privilegio, tras su paso por la factoría mediática de W. R. Hearst, ${ }^{2}$ de presidir la cúpula del CPI, flanqueado por

* Diego.Molla@uv.es 
los tres ministros del gobierno de Woodrow Wilson competentes en materia de guerra, Newton D. Baker (Secretary of War), Josephus Daniels (Secretary of the Navy) y Robert L. Lansing (Secretary of State), tendría, dos años después de la conclusión de la Primera Guerra Mundial, el privilegio de firmar la historia oficial del CPI, prologada por N. D. Baker. De las pretensiones historiográficas del relato da cuenta, también, el prologuista, quien se refiere a How We Advertised America en los siguientes términos: "it is not a compilation of incident and opinion, but a record and a chronicle" (1920: IX). ${ }^{3}$

How We Advertised America está dividido en dos secciones, "The domestic section" y "The foreign section" (1920). "The battle of the films" es el noveno capítulo de la primera; "Fighting with films", el cuarto de la segunda. Este artículo está dedicado al archivo icónico norteamericano de la Primera Guerra Mundial, al modelo de memoria que fue construyendo el relato historiográfico patrocinado institucionalmente $\mathrm{y}$, en particular, el silent cinema, en aquellos días en que los relatos cinematográficos: documentales y de ficción integraban un complejo dominio narrativo (Gavaldà 2013).

Through the medium of the motion picture, America's war progress, as well as the meanings and purposes of democracy, were carried to every community in the United States and to every corner of the world. "Pershing's Crusaders," “America's Answer," and "Under Four Flags" were types of feature films by which we drove home America's resources and determinations, while other pictures, showing our social and industrial life, made our free institutions vivid to foreign peoples. From the domestic showings alone, under a fair plan of distribution, the sum of $\$ 878,215$ was gained, which went to support the cost of the campaigns in foreign countries where the exhibitions were necessarily free (Creel, 1920: 8).

\section{El Committee on Public Information y la "Divi- sión" cinematográfica}

Las palabras acabadas de citar pertenecen al primer capítulo de How We Advertised America, "The second lines". La Primera Guerra Mundial diferiría "esencialmente" de todas las anteriores por el papel desempeñado, "with almost equal significance" (1920: 3), por el combate en "las segundas líneas", bien lejos, en el caso norteamericano, de la primera línea de fuego. ${ }^{4} \mathrm{G}$. Creel utiliza las mayúsculas para designar ese sujeto paradójico que emerge del constitucionalismo moderno, "la Opinión Pública”, ese nuevo sujeto que estaba tratando de manera tan mezquina la psicologia conductista y la doctrina de la "sociedad de masas", el que le conferiría a la guerra de 1914 su singularidad: "the recognition of Public Opinion as a major force” (1920: 3). En 1918, en su condición de presidente del CPI, G. Creel se refería así a la opinión pública: "the fight for public opinión is a part of the military program of every country" (Creeel, 1918: 185$).^{5}$

Las conclusiones de Propaganda Technique in the World War (1927), la obra de Harold Lasswell dedicada al CPI, utilizarán como referencia canónica la documentación de la U. S. Military Intelligence, en particular, un documento titulado Propaganda in its Military and Legal Aspects. ${ }^{6}$ Guerra, opinión pública y propaganda son los ejes temáticos definitorios de la extensa obra de Edward Bernays, ${ }^{7}$ en la que sobresale un texto justamente criticado, The Engineering of Consent, donde este dirá: "En la Primera Guerra Mundial, el famoso CPI organizado por G. Creel dramatizó en la conciencia pública la efectividad de la guerra de las palabras" (1955: 115).

Aunque en Estados Unidos, como en Europa, se levantaron voces contra la guerra, el consenso de la industria mediática, representación, supuestamente, de la opinión pública, fue demoledor. En el siglo XX la guerra debía ser objeto, en tantos Estados, del refrendo parlamentario. Los estados democráticos necesitaban desarrollar nuevas estrategias de legitimación para su política de guerra, dirigidas a las "primeras líneas" y a las "segundas líneas", a los ciudadanos movilizados y a los ciudadanos que habían de asumir la producción y la economía de guerra. Y los soldados movilizados eran, en tantos casos, ciudadanos con derechos, recogidos en las respectivas constituciones; los norteamericanos, ciudadanos procedentes, en tantas ocasiones, de los más variados rincones del mapa europeo. ${ }^{8}$ Ahora tenían que embarcar rumbo a Europa, a la guerra que la estaba devastando, tras unas elecciones ganadas, unos meses antes, por el candidato del Partido Demócrata, W. Wilson, para quien se había acuñado un expeditivo eslogan de campaña: "He us out of war" (D'Amery 2001). "The motion picture and the still photographs" fueron munición privilegiada en "las segundas líneas", "in the construction of a true picture of the American democracy", "in the fight for the minds of men, for the conquest of their convictions" (1920: 11).

En el CPI hizo sus primeras armas E. Bernays, quien realiza, en Propaganda (1928), un análisis detallado de la "técnica" desarrollada "por el gobierno norteamericano y las agencias patrióticas" a lo largo de la Primera Guerra Mundial con el objetivo de "reglamentar la mente" mediante "soportes visuales, gráficos y auditivos" 
(1928: 27). El "éxito arrollador de la propaganda", de los "manipuladores de la opinión patriótica", certificaría la posibilidad de "producir reacciones masivas" mediante "clichés mentales y hábitos emocionales", diseñados por "the intelligent few" (1928: 28). E. Bernays, como hemos visto, invoca abiertamente las virtudes de la "dramatización” en el diseño de las estrategias discursivas del CPI, lejos de la apelación a las falacias de la retórica de la objetividad que preside la valoración que hace G. Creel del que sería, supuestamente, "the one full and accurate record of America's war progress" (1920: 210). ${ }^{9}$

De la escrupulosa organización del ejército de las "segundas líneas" da cuenta un conjunto de capítulos de la primera "sección" del libro de G. Creel, "the domestic section": "the division of news" (cap. 6), "the four minute men" (cap. 7), "the division of filsm" (cap. 9), "the battle of fences" (cap. 10), "the war expositions" (cap. 11), "the speaking division" (cap. 12), "the advertising division" (cap. 13), "the division of sindicate features" y "the division of cartonists" (cap. 19). La línea de fuego de este frente se extendía "through every home in every country" (1920: 3). La actuación de todas estas "divisiones" fue primordial en la recogida de fondos, las campañas de reclutamiento, la incorporación de las mujeres a la industria armamentista y la neutralización de cualquier opinión contraria a la guerra.

La Primera Guerra Mundial, por una parte, detuvo el desarrollo de la radiodifusión, al convertir la radiofonía en logística bélica, pero, por otra, aceleró el despliegue de las redes de telecomunicación sin hilos y multiplicó el volumen de la fabricación de equipos radiofónicos. De ese despliegue se beneficiarían las agencias de noticias y la prensa, que pudieron extender su mapa y acelerar sus procesos comunicativos. "Por primera vez en la historia", dirá G. Creel, "los discursos presidenciales tuvieron una difusión universal” (1920: 10). En su exceso, esta aseveración ilustra los cambios provocados por el conflicto en el sistema comunicativo mundial, tal y como ha analizado A. Mattelart en La comunicación-mundo (1993), en el marco de la categorización de las relaciones entre "guerra y comunicación". En el caso norteamericano, aquel conflicto, mundial, fue la ocasión privilegiada para abordar dos déficits en los que insiste de manera reiterada How We Advertised America: el de las redes de telecomunicación, en un planeta regido, todavía, y ya por poco tiempo, por el imperio británico, y el de la producción de noticias, como consecuencia de la posición de dominio de la agencia Reuters. ${ }^{10}$ En palabras de G. Creel, "America controlled no cables, manipulated no press associations, operated no propaganda machinery of any kind"; de ahí que lamentara "la dependencia de las agencias de prensa extranjeras para el contacto con el mundo", (1920: 238), en un momento en el que "the stories" devenían «live news», «not the usual communiqué, but live news stories» (1920: 291).

La primera mención que hace How We Advertised America del discurso cinematográfico precisa, como hemos visto, la estrategia ideológica que vertebra la producción icónica norteamericana del periodo bélico, la indisoluble unidad de los dos ejes argumentativos que fundamentarán la vasta campaña de comunicación institucional desplegada por el gobierno norteamericano. La producción cinematográfica tendría un papel decisivo en la difusión de "the America's war progress" y de "the meanings and purposes of democracy", a lo largo y ancho de Estados Unidos y por todos los rincones del planeta. "The battle of films" proclamará la absoluta necesidad "to place the pictorial record of America's war progress", para lo que se considera decisiva la producción de "the Signal Corps's great Photographic Section”, "possessed of the very highest propaganda value” (1920: 120).

W. Wilson, el presidente que había hecho bandera electoral de la neutralidad en las elecciones de 1916 acompañó la declaración de guerra firmada en 1917, meses después de su victoria en las urnas, de la creación del CPI, un organismo primordial en la historia de la comunicación moderna. En Europa se habían creado organismos de comunicación clandestinos, encubiertos, responsables de abyectas campañas de "propaganda", siendo el británico modelo de referencia. El gobierno norteamericano optó por una solución bien distinta. Creó un Comité integrado por tres ministros y presidido por un periodista curtido con W. R. Hearst, el futuro autor de un relato en primera persona del plural, como tantos relatos de vencedores, a cuya edición le confieren un aire de devocionario la profusión de fotografías de los héroes seleccionados por el memorialista: "The First Telling of the Amazing Story of the Committee on Public Information that Carried the Gospel of Americanism to Every Corner of the Globe". El CPI tenía que enterrar el eslogan que había llevado a W. Wilson a la presidencia de los Estados Unidos.

H. Lasswell, "considerado por sus colegas como uno de los cuatro padres fundadores de la mass communication research", en palabras de A. Mattelart, "el inventor de la famosa fórmula (que supuestamente encierra las claves sociológicas de la comunicación de masas) de las 5W" (1993: 87), rendirá tributo, en Propaganda Techni- 
que in the World War, a la "monumental rhetoric" de W. Wilson, "the great generalissimo on the propaganda front": "He and Lenin were the champion revolutionists of the age. (...) Such matchless skill as Wilson showed in propaganda has never been equalled in the world's history" (1927: 216-217). ${ }^{11}$

El CPI desplegó una vasta y compleja estrategia de comunicación de Estado. ${ }^{12}$ Es, sin duda, el órgano de "propaganda” más poderoso creado durante el conflicto, aunque el gobierno norteamericano lo bautizó invocando dos categorías de inobjetable crédito democrático: información y publicidad, la información pública. En la tradición anglosajona la categoría de publicity es fundamento del nuevo sujeto y del nuevo espacio que vertebran las sociedades democráticas, la opinión pública y el espacio público (Habermas 1994). G. Creel no se arredraría, sin embargo, con esta tradición, como certifica el título de su obra, su valoración del éxito del "equipo de América": "it was a plain publicity proposition, a vast enterprise in salesmanship, the world's greatest adventure in advertising" (1920: 4). Estados Unidos contaba con la industria publicitaria más desarrollada del mundo. Esta, alineada en "The advertising division", tenía motivos sobrados para aplaudir con calor la mixtura de G. Creel, que sería consagrada a partir de la siguiente década por el modelo de mercadotecnia política desarrollado por la administrive research. El ámbito de la advertising, de acuerdo con el presidente del CPI, habría comenzado la guerra como un business para acabarla con "the recognition as a real profession” (1920: 157-158).

"The advertising division", subrayará G. Creel, habría sabido establecer vínculos estratégicos con «the division of pictorial publicity», «the division of films», «the four minute men», «the division of cartoonists»; habría obtenido éxitos arroladores con su «division of distribution» y su «Advertising Service Bulletin», especialmente en las campañas de promoción de los bonos patrióticos. Habría ahorrado hasta cinco millones de dolares al gobierno norteamericano gracias a la obtención de espacios publicitarios gratuitos en toda classe de soportes. Al "ejército de expertos publicitarios" se le reconoce la condición de "parte de la maquinaria del gobierno", fundamental en el "combate en las segundas líneas". La existencia del CPI quedaría sobradamente justificada aunque solo fuera por su contribución a la "dignificación de una professión", a "la incorporación de su dinamismo al equipo de América” (1920: 165).

Publicity y advertising convivirían, pues, en perfecta armonía, alejadas, por supuesto, de la "propaganda":
"We did not call it propaganda, for that word, in German hands, had come to be associated with deceit and corruption. Our effort was educational and informative throughout" (1920: 4). Cuando llegue la Segunda Guerra Mundial, con lo europeos embarcados en faraónicas instituciones de "propaganda", con rango de ministerio, dirección general o secretaría, los norteamericanos seguirán por su camino, ahora con menos pompa: su "Office of War Information” (OWI) será solo "de guerra”, pero nada menos que "informativa".

La Primera Guerra Mundial aceleró el paso de la industria cinematográfica norteamericana y acabó inclinando a su favor la balanza de la producción cinematográfica mundial. La barbarie desató la demanda de información, por encima de cualquier otra, visual, y la irrupción del CPI, como veremos, agitó las aguas del mercado cinematográfico norteamericano. El Comité contaba con una industria incipiente, lejos todavía de la que podría movilizar en su momento la OWI, cuyo Bureau of Motion Pictures produciría "cine informativo" a gran escala, con la participación de reputados productores, directores, guionistas y actores procedentes del cine de ficción, enrolados todos ellos en el ejército norteamericano. Al CPI le correspondió el honor de abrir ese camino.

El Comité consiguió una exclusiva primordial, la llave del principal banco de imágenes: las obtenidas en primera línea por el ejército norteamericano, por la Photographic Section del Signal Corps: "The CPI was recognized by the War Department as the one authorised medium for the distribution of Signal Corps photographs, still pictures as well as movies" (1920: 118). El uso de las mismas quedará taxativamente estipulado en el primer capítulo del libro del presidente del CPI, "The second lines"; y en el segundo, "The "censorship" bugbear". Era la hora del patriotismo, del "aroused patriotism", de la "voluntary censorship in terms of human life and national hopes" (1920: 24), de la censura patriótica, en las "primeras" y en las "segundas líneas". El autor de la hagiografía del "equipo de América" proclamaría sin rodeos:

Many a good and misinformed citizen, who had an unformed but vivid impession that the "Creel Committee" was some iniquity of the devil, took with his breakfast a daily diet of our material from the same journal that had given him this impression, met us again at lunch when his children came home with what the teacher had given them from material we prepared, heared us again through our Four Minute Men organization when he went to the "movies", where our films might be part of the program, and rose to local prominence by the 
speeches he drew from the pamphlets of that other useful organization, the Committee on Public Information (1920: 109-110). ${ }^{13}$

La contribución del CPI a la pesadilla de la censura ha sido enjuiciada por muchos estudiosos. La involución ultraconservadora del gobierno del Partido Demócrata la ampararon un conjunto de leyes, "The Espionage Act", "The Trading with the Enemy Act" o "The Sedition Act", que permitieron encarcelar y diezmar a quienes se opusieron a la guerra.

Walter Lippmann firmaría uno de los balances más sombríos del CPI. Un año después de la publicación de How We Advertised America, este había concluido Public Opinion, una obra capital para la communication research del siglo $\mathrm{XX}$.

Sus páginas translucen el impacto de la vasta campaña de comunicación de Estado desplegada por el gobierno norteamericano en la Primera Guerra Mundial y permiten apreciar el papel que se le concede a la imagen en la representación de la actualidad, en la producción de opiniones. ${ }^{14} \mathrm{El}$ segundo capítulo de Public Opinion se titula «Censorship and privacy» y en su conclusión subraya «la distancia que a menudo separa a la opinión pública del acontecimiento sometido a consideración" (1961: 45). Esa "distancia" sería primordial en el modelo comunicativo de la "propaganda", que requiere, de manera ineluctable, "alguna forma de censura", la capacidad de "impedir el acceso independiente a los acontecimientos", "alguna barrera entre el público y los acontecimientos", algo que no podría ser justificado, en ningún caso, invocando "motivos patrióticos" (1961: 42-44). El tercer capítulo de Public Opinion despacha "the machinery" de G. Creel con el mínimo espacio y el máximo desprecio, sin referirse en ningún momento de manera explícita al CPI, omnipresente en todas las páginas del libro: "probably the largest and the most intensive effort to carry quickly a fairly uniform set of ideas to all the people of a nation", "something that might almost be called one public opinión all over America” (1961: 47).

Bien es verdad que el CPI contó con incondicionales de la talla de H. Lasswell, quien le dedicó su tesis doctoral, Propaganda Technique in the World War, donde se define la propaganda como "la nueva llama que ha de templar el acero del entusiasmo belicoso", "uno de los instrumentos más poderosos del mundo moderno" (1927: 25). H. Lasswell, cultivador de la psicología experimental, del "empirismo cuantitativo" (Mattelart 1993: 88), condena las campañas de propaganda francesa, inglesa y alemana y loa las excelencias del CPI, "the central clearing house", la sede de un "servicio nuevo y experimental", la "propaganda", que exigía "the daily balancing and weighing of delicate currents of public sentiment" (1927: 27-28). Había nacido una nueva profesión, la del "propagandista": "the modern world is busy developing a corps of men who do nothing but study the ways and means of changing minds or binding minds to their convictions" (1927: 34).

"Las nuevas actividades", dirá E. Bernays, un año despúes, en Propaganda (1928), "exigen nuevas nomenclaturas”. El "propagandista” es, por una parte, el especialista en "interpretar para el público ideas y proyectos", y, por otra, "el especialista en interpretar al público para los promotores de nuevos proyectos e ideas". Esta nueva figura, responsable de este nuevo modelo de estrategia comunicativa, "se denomina the public relations counsel" (1928: 37-38)..$^{15}$

Finalizada la Primera Guerra Mundial habían sufrido una represión selectiva y feroz las organizaciones y sindicatos de izquierda, en especial, el Partido Socialista de los Estados Unidos, y las organizaciones de mujeres que habían levantado la bandera pacifista (Vaughn 1980). La "división” cinematográfica del CPI haría gala de un patriotismo acendrado, aplicándose con esmero en la censura "voluntaria" y en las artes del "mensaje verdadero","possitive and open", "para dar a los americanos todos los hechos, para contar la totalidad de la historia" (1920: XIV).

The spirit of cooperation reduced the element of friction to a mínimum. Oftentimes it was the case that a picture could be made helpful by a change in title or the elimination of a scene, and in no instance did a producer fail to make the alterations suggested. During its existence, according to the report of Lieutenant Tuerk, more than eight thousand motion pictures were reviewed, the greater percentage of which went forward into foreign countries with the true message from America (1920: 282).

\section{La producción y la distribución cinematográfica}

El silent cinema acogió a la verbalidad en la medida de sus posibilidades. Los "titles" tenían la virtud de constituir un material agradecido, tanto para el trabajo del censor como el de los traductores, "the tedious job of putting the titles into the various languages" (1920: 274), en un momento en que aquella industria incipiente tenía que multiplicar su producción a un ritmo vertiginoso (1920: 121). 
La llave del principal archivo de imágenes concedió al CPI un poder de persuasión irresistible, como lo prueban los contratos firmados con The Hearst-Pathé, The Universal, The Mutual y The Gaumont (1920: 123124). Sus prerrogativas en el mercado cinematográfico norteamericano eran ilimitadas, aunque su prioridad, proclamada una y otra vez, era "to avoid all appearence of competition with the commertial producers, and as a consequence the bulk of material was distributed fairly and at a nominal price among the film-news weeklies" (1920: 121). Sus lazos no solo anudaban, por supuesto, a los productores de cine informativo. El modelo de distribución que acabó sellando el CPI da cuenta, como veremos a continuación, de su capacidad para influir tanto en los aspectos industriales como en el diseño de las estrategias discursivas.

"A well-balanced program", un calculado equilibrio entre la producción de información y de ficción, ese era el objetivo del CPI, la enseña de su "división" cinematográfica, en el circuito doméstico y en el internacional (1920: 275). Los films "educativos" debían acompañar, en cualquier sesión, "the Armerican comedy and dramatic film”, los demandados por los exhibidores (1920: 275). Las medidas adoptadas obraron milagros. Ninguna película podía salir de los Estados Unidos sin pasar por el War Trade Board y contar con "the indorsement of the Committee on Public Information": "the rest was simple" (1920: 275). El CPI garantizó "its influence to expedit film shipments" (1920: 276) y, en contrapartida, exigió de la industria un compromiso "in equal degree":

1. That every shipment for entertainment film from the United States should contain at least 20 per cent "educational matter".

2. That not a single foot of American entertainment film would be sold to any exhibitor who refused to show the Committee's war pictures

3. That no American pictures of any kind would be sold to houses where any sort of German film was being used (1920: 276).

Además de colocar sus películas en multitud de países, el CPI consiguió, por supuesto, "to keep certain motion pictures out of these countries" (1920: 281). "Our arrangements with the War Trade Board gave us power and we exercised it", concluye, sin tapujos, G. Creel (1920: 282). El CPI blandió el "shipping space" y la industria "cooperó con entusiasmo": "Not only was it the case that all harmful film was barred from export, but producers became more and more willing to incorpo- rate a large percentage of "educational pictures" in their shipments” (1920: 282).

Hubiera sido inconcebible que las cosas en casa no discurrieran por los mismos derroteros. Los espectadores norteamericanos gozaron, además, del trabajo de una de las "divisiones" que mayor gloria darían al CPI, "The Four Minute Men", "the organization of volunteer speakers for the purpose of making patriotic talks in motion-pictures theaters" (1920: 84). En el exiguo espacio de tiempo que mediaba entre la información y la ficción de aquellos programas "well-balanced" comparecían quienes cifraban la agenda de la jornada al dictado del CPI, en un tiempo impropio de acuerdo con las pautas de la predicación más añejas y absolutamente apropiado según los parámetros de una publicidad que se abría camino vertiginosamente. La "división" estaba a las órdenes de E. T. Gundlach, "the patriotic head of an advertising agency" ${ }^{16}$

\section{La narración y la puesta en escena del cine bélico}

No fue esta la única línea de actuación en pos del “well-balanced program”. Las quejas por aquel peaje al que G. Creel se refería, indistintamente, como "education cinema" o "propaganda pictures", arreciaron en casa y fuera: "the general attitude of motion-picture exhibitors was that propaganda pictures were uninteresting to audiences and could have no regular place in their theaters" (1920: 126). Y aunque la segunda línea de actuación de la "division of films" no tuvo el rango y el encaje institucional de la primera resultaría crucial para la definición de la estrategia discursiva de aquel cine bélico. La actuación revela el tenor del talante "educativo" de todas las ofensivas emprendidas por el otro ejército, en el que estaba encuadrada una "división" cinematográfica que no se conformaba con unos "contratos adicionales" consagrados "a asegurar una difusión más o menos limitada de los films producidos". Además, la "batalla de los films "propició la creación de un "scenario department" para experimentar con una "interesting theory" (1920: 126).

The theory of the Division of Films was that the fault lay in the fact that propaganda pictures had never been properly made, and that if skill and care were employed in the preparation of the scenarios the resultant pictures could secure place in regular motion-picture programs. Producers were at first skeptical, but in the end they agreed to undertake the production of one-reel pictures for which the division was to supply the scenario, the 
list of locations, and permits for filming the same, and to give every possible co-operation, all without charge. The finished picture became the sole property of the producer, who obligated himself merely to give it the widest circulation after it had been approved by the Division of Films (1920: 126-127).

No se descuidaban, por tanto, aspectos cruciales para un modelo de economía de la comunicación como el norteamericano, estrictamente vinculado al mercado, tanto en la implantación de las redes de telecomunicación, primero, como en la constitución de los sucesivos dominios del sistema mediático, después; ni los relativos a los derechos de propiedad y a los costes de producción. $\mathrm{Ni}$, por supuesto, los relativos a "the "censorship" bugbear". Algunos de los títulos, de la amplia lista de films producidos por The Paramount-Bray Pictograph, The Pathé Co., The Universal Co., The W. W. Hodkinson Corporation o C. L. Chester, permiten colegir el alcance y el horizonte de aquella batalla "educativa": "Says Uncle Sam: a Girl's a Man for A'That (story of women in war-work), Says Uncle Sam: I'll Help Every Willing Worker Find a Job (story of the United States Employment Service), The American Indian Gets Into the War Game (how the Indian took his place, both in the military forces and in food production), Colored Americans (activities of the negroes, both in the military forces and in war work at home), Waging War in Washington (the method of government operation), Made in America (an eight-reel picture telling the full story of the Liberty Army)"17 (1982: 127-128).

Se trataba, pues, de un modelo de diseño de producción legitimado patrióticamente, devoto de la censura "voluntaria” y, supuestamente, sin ánimo de lucro. La "división" cinematográfica ampliaba su campo de actuación, adentrándose en la configuración de las estrategias narrativas y en el diseño de la puesta en escena. Y aunque en un primer momento pudo contentarse con el guion y las localizaciones, algo que era más que suficiente para tantas de las "one-reel pictures" de vuelo corto, amplió muy pronto su radio de acción. Made in America, modelo de virtud para la Morale Branch del War Department, constituye un ejemplo revelador: "As this picture was to show the relation of the home life to the soldier, profesional actors and actresses and much studio-work were required"18 (1982: 128).

La frontera entre los relatos documentales y los relatos de ficción siempre había sido difusa, desde los orígenes del cinematógrafo. Ambos compartían ese "aire de familia” al que se referiría Ludwig Wittgenstein en su definición de los “juegos de lenguaje” (1983); se inscribían en esa "unidad funcional entre las modalidades narrativas" de la que hablaría Paul Ricoeur. ${ }^{19}$ Ambos compartían principios constructivos narrativos, y uno y otro se regían por sus respectivos contratos pragmáticos, en tanto que relatos documentales y relatos de ficción (Gavaldà 2013). La guerra aceleró el paso de la industria cinematográfica, multiplicó la producción de los dos modelos discursivos que iban definiendo y determinando su dominio en el seno de la cultura del siglo XX, el modelo que lo emparentaba con lo mediático, el del "cine informativo", y el que lo inscribía en lo artístico.

El modelo de hibridación propugnado por el CPI representaba los designios más genuinos de las estrategias de "propaganda". "The division of films" empleaba en sus relatos "informativos", "educativos", las tácticas de los relatos de ficción, mientras "the division of news" proclamaba "the colorless style", "without cutting and colouring", "without color or bias", "only facts, information, statistics", "only frank, complete and accurate chronicle" (1920: 72-75). How We Advertised America abona un oxímoron que continúa gozando de amplio predicamento, que fue primordial en las campañas de "propaganda" de la Primera y la Segunda Guerra Munidal: «factual information». ${ }^{20}$ El CPI sería artífice, de acuerdo con G. Creel, de «a continuous presentation of facts»; ni representanción ni enunciación, estrictamente "presentación". Se trata de otro modelo discursivo edificado, en los términos de Umberto Eco, sobre la "falacia referencial" (2000).

La "teoría”, por supuesto, "proved sound", y se decidió "to undertake production on our own account": "scenarios were written and six two-reel pictures were produced by the division, If Your Soldier's Hit, Our Wings of Victory, Our Horses of War, Making the Nation Fit, The Storm of Steel and The Bath of Bullets (1982: 128-129). El armisticio detendría una segunda serie para la que ya se había realizado un importante trabajo de preproducción. El CPI acabó alcanzando su destino más previsible. Se convirtió en "productor y exhibidor" (1920: 121).

\section{4. "The Gospel of Americanism"}

Estados Unidos firmó su declaración de guerra en 1917. La Primera Guerra había cubierto ya un largo trecho. Ese año Europa continuó viviendo la tragedia de la guerra y experimentó la sacudida de la revolución soviética. El gobierno norteamericano tuvo bien presentes una y otra en la represión que amordazó el sistema de- 
mocrático con el auxilio de las leyes anteriormente mencionadas, al igual que el CPI, en sus campañas "domésticas" e "internacionales". ${ }^{21}$

El calendario de actividades de la "división" cinematográfica fue muy corto. La producción cinematográfica, de ficción e informativa, estaba en el inicio de la que sería una prodigiosa andadura. La "teoría" cinematográfica del CPI no pudo recorrer un trecho significativo, sin embargo su semilla fructificaría en la Segunda Guerra Mundial, en la Guerra Fría. Sus títulos resonarán en muchos relatos bélicos, documentales y de ficción.

A pesar de las dimensiones de la industria cinematográfica, del volumen de su producción en ese momento, How We Advertised America le concede un lugar de privilegio al cine, dos capítulos, uno en la sección "doméstica” y otro en la "internacional”. La fascinación que provocaba la imagen en movimiento, la aureola referencialista que dotaba de un poder ilimitado a su modelo de representación en aquellos momentos inaugurales, ${ }^{22}$ corría pareja con el menosprecio de la torre de Babel. El cine tiene capítulo en la sección internacional, "Fighting with films”, porque a él se fian los más altos designios. Bastaba, supuestamente, con mover los "titles". Era obligado hacerlo fuera y en casa, donde se hablaban en aquellos momentos, como se ha señalado, hasta treinta $\mathrm{y}$ tres lenguas. La sociedad norteamericana necesitaba aquella argamasa a la que consagró su trabajo el CPI, "the Gospel of Americanism", fundamento de la candidatura imperial que ya habían comenzado a presentar los Estados Unidos: "to make our free institutions vivid to foreign people”, como hemos leído al comienzo de estas páginas. Las tramas y personajes de aquella producción cinematográfica fueron alumbrando un universo simbólico, sus estrategias narrativas cimentaron un modelo de discurso político, un modelo de memoria que legó a un siglo que acabaría hastiado de mitogenia bélica, patriótica. W. R. Hearst, personaje de Hollywood, una de las novelas históricas de G. Vidal, confiesa:

- Si yo no sé nada de cine - dijo Caroline.

- Nadie sabe-dijo Hearst-. Esto es lo maravilloso. Mira, mientras nosotros estamos aquí sentados, todos los analfabetos chinos, hindúes y patagones del mundo están mirando a mi Pauline. ¿Ves? Para ver una película no necesitas saber otra lengua, como sucede cuando tienes que leer un periódico, porque está todo allí, en la escena, moviéndose de un lado para otro. Es la única cosa internacional que existe (1990: 11).

Hemos perdido, desgraciadamente, buena parte del archivo cinematográfico mundial de aquellos años, informativo y de ficción. El CPI, como hemos visto, adoptó medidas estrictas para que la fortuna de ambos corriera pareja en aquellos días de guerra, en los que la industria cinematográfica norteamericana comenzó a tejer un imaginario esencial para la iconosfera contemporánea. “The America’s war progress" y "the meanings and purposes of democracy" fueron competencia de los dos relatos cinematográficos, documental y de ficción. Además, como hemos señalado, se promovieron modelos de hibridación entre uno y otro que se encargarían de hacer fructificar todas las guerras del siglo que acababa de comenzar. Fue por aquellos días, los del nacimiento de "the Gospel of Americanism", cuando echó a andar la guerra que atravesaría todo el siglo XX.

Mientras tanto, la mente rápida, enérgica y cruda de Creel había asimilado la idea de la película sobre Debs; y le había parecido buena.

- ¿Sabe qué le digo, Señor Farrell? Es una idea inspirada. Tiene usted toda la razón. Nos ha mostrado a los alemanes del infierno. Bien, ya nos hemos ocupado de ellos. Y qué viene a continuación. Los bolcheviques, el comunismo, el socialismo, los agitadores sindicales, el enemigo dentro de nuestro propio país. Es el peligro real de hoy. Muestre a Debs y a Trotsky trabajando juntos para esclavizar a todos y cada uno de los americanos, algo que ni los alemanes habían soñado porque ambos éramos naciones cristianas con los mismos sistemas capitalistas. Pero los bolcheviques tienen una nueva religión que podría despegar en este país. Mire las huelgas de ferrocarriles, las de las minas de carbón..., no podrá decirme que no hay alguien manipulando a nuestros trabajadores para destruir nuestras libertades... Creel estaba fuera de sí ante la perspectiva de aquella nueva cruzada (1990: 179).

G. Creel es otro de los personajes, de ficción, de $\mathrm{Ho}^{-}$ llywood, una novela histórica sobre la Primera Guerra Mundial cuyo protagonista es Hollywood. Le debemos a G. Vidal esta esclarecedora hibridación, esa trama narrativa que se acoge a un topónimo que acabaría iluminando al planeta. Eugene V. Debs, fundador del Sindicato Ferroviario y del Partido Socialista de los Estados Unidos, había conseguido un millón de votos en las elecciones a la Presidencia celebradas en 1912. Participaría en las de 1920 desde la cárcel, donde cumplía una condena de tres años por haber participado en un mitin contra la guerra en Ohio. En El último imperio, G. Vidal rememora sus días escolares, las lecturas de aquellos años, la de la biografía de George Washington, "la típica hagiografía que toda nación obliga a digerir a sus cachorros con objeto de que sean tan buenos patriotas que luchen en guerras que nada tienen que ver con ellos, al tiempo que pagan impuestos por semejante privilegio" (2002: 77-78). 


\section{Referencias}

Bazin, A. (1975). “Ontologie et langage” en Qu'est-ce que le cinéma, 1. Paris: Editions du Cerf.

Bernays, E. (1928). Propaganda Retrieved from http://www.historyisaweapon.com/defcon1/bernprop.html [Consultado el 15 de noviembre de 2015]

The Engineering of Consent. Retrieved from http://gromitinc.com/lego/Library/Engineering_of_consent.pdf [Consultado el 15 de noviembre de 2015]

Creel, G. (1918). "Public Opinion in War Time”, en Annals of the American Academy or Political and Social Science, 78, pp. 185-194.

(1920). How We Advertised America. New York: Harper\&Brothers Publishers.

D’Aymery, G. (2001). «Propaganda: Then and Now». Retrieved from http://www.whatreallyhappened.com/WRHARTICLES/ propaganda.html?q=propaganda.html [Consultado el 15 de noviembre de 2015].

Eco, U. (2000). Tratado de semiótica general. Barcelona: Lumen.

Gavaldà, J. (2013). “Hibridación discursiva y programación televisiva: infoshow y docufiction”, en AA. VV. El documental en el entorno digital. Barcelona: UOC.

Habermas, J. (1994). Historia y crítica de la opinión pública. La transformación estructural de la vida pública. Barcelona: G. Gili.

Lasswell, H. (1927). Propaganda Technique in the World War. New York: P. Smith.

Lippmann, W. (1961). Public Opinion. New York: Macmillan.

Mattelart, A. (1993). La comunicación-mundo. Historia de las ideas y de las estrategias. Madrid: Fundesco.

Ricoeur, P. (1987). Tiempo y narración I, II, III. Barcelona: Cristiandad.

- (1999). Historia y narratividad. Barcelona: Paidós.

- (2000).”Narratividad, fenomenología y hermeneútica”, Anàlisi, 25.

Rorty, R. (1996). Consecuencias del pragmatismo, Madrid: Tecnos.

Sloterdijk, P. (2003). Temblores del aire. Valencia: Pre-Textos.

Vaughn, S (1980). Holding Fast the Inner Lines: Democracy, Nationalism, and the Committee on Public Information. Chapel Hill: University of North Carolina Press.

Vidal, G. (1990). Hollywood. Barcelona: Edhasa.

- (2001). El último imperio. Madrid: Síntesis.

Wittgenstein, L. (1983). Investigacions filosòfiques. Barcelona: Laia.

\footnotetext{
1 Es incomprensible que no se haya traducido al español precisamente este libro, fundamental para la historia de la mass comunication norteamericana y, como veremos, para la, por entonces, incipiente mass comunication research, la administrative research, el paradigma que ha gozado, y continúa gozando, de ilimitado crédito institucional en la investigación mediática
}

2 Gore Vidal lo retrata sin piedad en las páginas de Hollywood: “un presuntuoso hombre publicitario, que pensaba en forma de eslóganes, un hombre perfecto para Hearst” (1990: 97).

3 Por debajo de las "fuerzas físicas” y los "factores industriales”, asegura el Ministro de la Guerra, los "futuros historiadores" sabrán descubrir las "fuerzas mentales" y las "ideas", "el invencible poder de nuestros ideales”, el "idealismo" y el "espíritu”, "el verdadero espíritu y el idealismo de América”, nuestra "Moral Nacional” (1920: XV). El apéndice de How We Advertised America lo cierra una carta en la que G. Creel defiende la contribución del CPI a la "creación de una moral nacional” (1920: 454). El Ministerio de la Guerra había creado una Morale Branche, dirigida por el general E. L. Munson, con la que trabajó estrechamente el CPI. Este tuvo una historia muy corta, pero fructífera. En julio de 1940 se constituiria el Committee for National Morale, del que formó parte el general E. L Munson. Su documento fundacional, “A plan for a National Morale Service”, propuso una solución ensayada por el CPI en la anterior guerra mundial: frente a la "propaganda”, la "moral”. De este Committee for National Morale formó parte Elmer Davis, futuro director de la Office of War Information.

4 Peter Sloterdijk ha señalado que la Primera Guerra Mundial “pasará a la memoria histórica como la época en que la idea decisiva de la guerra ya no es apuntar al cuerpo del enemigo" (2003: 45). Se produciría "el paso de la guerra clásica al terrorismo", al "modelo atmoterrorista" representado por "la guerra del gas", que extiende el terror a las "operaciones en la zona de guerra ampliada" (2003: 58). Los discuros mediáticos servirían para "sumergir poblaciones nacionales enteras en climas tendenciales generados estratégicamente, formando de este modo la analogía informativa del desencadenamiento de la guerra química” (2003: 134).

5 Los George Creel Papers pueden consultarse en la Biblioteca del Congreso http://rs5.loc.gov/service/mss/eadxmlmss/eadpdfmss/2010/ms010162.pdf [Consulta: 15 de noviembre de 2015]. 
6 Este modelo de análisis de la propaganda será fundamental en los trabajos del Institute for Propaganda Analysis, creado la década siguiente.

$7 \quad$ Las más relevantes del periodo que nos ocupa serían: Crystallizing Public Opinion(1923), A Public Relations Counsel (1927), Veredict of Public Opinion on propaganda(1927), Propaganda (1928), "Manipulating Public Opinion: The Why and The How" (1928), “The Marketing of National Policies: A Study of War Propaganda” (1942).

8 G. Creel contabiliza hasta treinta y tres lenguas en suelo norteamericano y destaca que el número de ciudadanos norteamericanos que tenían dificultades con el inglés o simplemente no lo hablaban era muy importante, lo que obligaba al CPI a diseñar estrategias específicas de "propaganda" para un colectivo tan heterogéneo. Como veremos, el silent cinema constituirá una herramienta privilegiada en este campo. Tres capítulos de How We Advertised America están dedicados a «the immigrant aliens», reconociendo el "exiguo papel que habían desempeñado en el afecto y el pensamiento de América” (1920: 173). "The Americanizers" (cap. 14) y "A wonderful fourth of July" (cap. 16), desarrollan la "teoría Americana de la unidad" (1920: 167), mientras "The work among the foreign-born" (cap. 15) define los fundamentos del "trabajo" requerido por esa parte decisiva, entonces, de la sociedad norteamericana.

9 E. Bernays, el patriarca de las Relaciones Públicas y el creador de algunas de las campañas publicitarias más reputadas de la historia, como "Torches of Freedom", de la que hace una aviesa mención el primer capítulo de la serie Mad Men, era sobrino de Sigmund Freud. Tras la disolución del CPI abrió en New York, el año 1919, la primera empresa de Relaciones Públicas. "Acabada la guerra", dirá E. Bernays, "era natural que las personas inteligentes se preguntaran si no era posible aplicar una técnica similar a los problemas de la paz” (1928: 27-28). La política había sido "el primer ámbito de la vida americana que utilizó la propaganda a gran escala”. Como señalaría G. D’Aymery, “E. Bernays took the techniques he learned in the CPI directly to Madison Avenue and became an outspoken proponent of propaganda as a tool for democratic government (2001).

10 No olvida G. Creel a "the Havas Agency", que le permitiría también a Francia, con el concurso de sus "cable arteries", "to conduct a governamental propaganda", "to direct currents of public opinión in channels favorable for themselves" (1920: 238).

11 En su canónico manual sobre la "propaganda”, H. Lasswell concluye que no tuvo la menor importancia que al frente del CPI se colocara un hombre "of tremendous energy, but little reputation", "that Mr. Creel lacked prestige": "The foreign policy of the country was made by President Wilson, and it happened to have great propaganda value” (1927: 29).

12 El relato de G. Creel conjuga el recurso permanente a las metáforas bélicas con un balance contable escrupuloso hasta en las unidades: los "four minute men", por ejemplo, habrían alcanzado la cifra de "75.000 speakers" y sus 755.190 discursos habrían cosechado una «audiència total» de 314.454.514 personas (1920: 94). En la financiación del CPI habría sido determinante el sentido del negocio de las distintas "divisiones" y, sobre todo, la "generosidad” de la movilización patriòtica. El balance, de acuerdo con el cronista gubernamental, arrojaría un saldo inigualable: "a world-fight for the veredict of mankind and all for less than five millions, less than half what Germany spent in Spain alone!” (1920: 13).

13 La movilización de la comunidad universitaria, y muy en especial del National Board for Historical Service, permitiría una copiosa edición de "publicaciones populares", alejadas, dirá G. Creel, de los textos "voluminosos y tediosos", aunque con un indiscutible "valor educativo e intelectual”. Red, White and Blue Books será una de las colecciones emblemáticas. Su primer volumen fue How the War Came to America.

${ }_{14}$ Picture es una categoría central en la definición de la opinión pública que propone W. Lippmann: "the world outside and the pictures in our heads", "the picture of Europa and Europa". Un abismo separa "las imágenes de nuestra mente" y "el mundo exterior", "los pseudo-acontecimientos y los acontecimientos". Y aunque las razones de esa cesura no son, en absoluto, coyunturales, lo cierto es que las estrategias comunicativas de guerra agrandarían esa brecha. Era inevitable que la primera referencialización de esta categoría fuera Europa: "the picture of Europe". W. Lippmann, incondicional de W. Wilson, era otro ciudadano norteamericano de origen europeo, alemán.

15 H. Lasswell y E. Bernays serían dos genuinos representantes de aquellos “científicos sociales” norteamericanos certeramente retratados por su compatriota Richard Rorty, de aquellas "primeras generaciones de científicos sociales norteamericanos”, erigidos “en apóstoles de una nueva forma de vida social”, que acabarían provocando, décadas después, el "desengaño” de los intelectuales americanos, por su papel en la construcción de "unas ciencias sociales “conductualizadas” y cómplices del Estado” (1996: 294).

16 Su trabajo no se redujo a las salas cinematográficas y con el tiempo fueron secundados por “the Women’s Divisions” y por “the Junior Four Minute Men Division”. How We Advertised America administra sin rubor la legitimación institucional: el capítulo dedicado a los "four minute men" concluye con una carta de W. Wilson ponderando su "remarcable record of patriotic accomplisment" (1920: 97).

17 "Made in America" no es una más de las producciones del listado ofrecido por How We Advertised America: "Such a picture was greatly desired by General Munson, head of the Morale Branch of the War Departmernt, for circulation in the army and among the people of the United States, as well as abroad" (1920: 128).

18 Las vicisitudes de la gestación del film constituyen un ejemplo privilegiado de las rutinas que conformaban la producción de aquella industria cultural. La Morale Branch no tenía fondos para participar en la producción de una historia que debía conocer bien antes de empezar a rodarse, pero la "división" cinematográfica "was able to work out a scenario of such promise that the Hodkinson Corporation agreed to produce the picture at their own expense, which they did at a cost exceeding forty thousand dollars" (1920: 128). 
19 P. Ricoeur ha realizado un valioso análisis de las relaciones entre "relato histórico y relato de ficción” (1999), de las "modalidades dispersas del juego de narrar", de la "unidad funcional entre los múltiples modos y géneros narrativos" (2000: 190): "uno en un mismo problema ficción, historia y tiempo" (2000: 191). Su definición de la tramat permite inscribir el análisis de las relaciones entre lo real y el discurso en el seno de la categorización de las distintas estrategias narrativas, de los principios constructivos del relato (Gavaldà 2013).

20 Dos meses antes del ataque a Pearl Harbour se crearía la Office of Facts and Figures, para desarrollar "la estrategia de la verdad", "to disseminate factual information". Esa oficina ya dispondrá de una munición privilegiada, la representación estadística de la opinión pública que habían comenzado a suministrar las instituciones y empresas demoscópicas, como el American Institute of Public Opinion, cuyo director, George Gallup, formaba parte del Committee for National Morale, y la adminstrative research, sobre todo, el grupo de investigación de Paul Lazarsfeld. La Office of War Information, heredera del CPI, creará diferentes organismos, como el Bureau of Motion Pictures, con sede en Hollywood. Una de sus producciones emblemáticas será la serie documental Why We Fight, coordinada por Frank Capra. El documental que cierra la serie, War Comes to America, hereda el título de una publicación del National Board for Historical Service para el CPI, How the War Came to America, y explota a fondo el modelo "facts and figures”. War Comes to America, el documental de F. Capra que enmarca la serie, recorre 334 años de historia para legitimar una doctrina primordial en el trabajo de CPI, teniendo en cuenta la heterogeneidad étnica de la ciudadanía norteamericana, la de "la unidad de América". How the War Came to America había sido el primer título de una colección emblemàtica del CPI, Red, White and Blue Books.

21

Cuando llegue la Guerra Fría G. Creel se enrolará en la división del cazador Jospeh McCarthy.

22 En Public Opinion, W. Lippmann emitía un diagnóstico muy extendido a principios de los años veinte: Photographs have the kind of authority over imagination today which the printed word had yesterday, and the spoken word before that. They seem utterly real. They come, we imagine, directly to us without human meddling, and they are the most effortless food for the mind conceivable. Any description in words, or even any inert picture, requires an effort of memory before a picture exists in the mind. But on the screen the whole process of observing, describing, reporting, and then imagining, has been accomplished for you (1961: 92) Es una concepción de la representación icónica, y, particularmente, del discurso cinematográfico, deudora del referencialismo de siempre y de la fascinación provocada por los primeros compases del "milagro" de la imagen en movimiento. Recién terminada la Segunda Guerra Mundial André Bazin haría una valoración de las relaciones entre representación verbal y representación icónica en el marco del relato cinematográfico documental que permite apreciar el camino andado de la Primera a la Segunda Guerra Mundial, agotado el embrujo de una imagen cinematográgica víctima, entre otras cosas, de los estragos de la propaganda: "Le spectateur a l'illusion d'assister à une démonstration visuelle, quand celle-ci n'est en réalité qu'une suite de faits équivoques ne tenant que par le ciment des mots qui les accompagnent. L'essentiel du film n'est pas dans la projection mais dans la bande sonore (1975: 75). 